\title{
The Royal Portuguese Cabinet of Reading: a space for medical science in the 19th century
}

\section{Real Gabinete Português de Leitura do Río de Janeiro: um espaço para a ciência médica Oitocentista}

DOl: http://dx.doi.org/10.1590/2236-463320161410

Monique de Siqueira Gonçalves

Universidade Estadual do Rio de Janeiro, Rio de Janeiro - RJ, Brasil monique.eco@gmail.com

Tânia Bessone

Universidade Estadual do Rio de Janeiro, Rio de Janeiro - RJ, Brasil bessone@ uol.com.br

\begin{abstract}
This work presents an analysis on the role of the Royal Portuguese Cabinet of Reading during the second half of the 19th century regarding the collection and safekeeping of medical science books. By analyzing the books contained in the 1906 catalog by Ramiz Galvão (consisting of the institution's collection since 1837), we intend to understand the relative importance of the medical science collection found in the general collection of the Royal Portuguese Cabinet of Reading, and whether it was updated and relevant amidst the constitution of Brazil's medical science field. It is also intended to discover the preponderant idiom among its works and at which target audience they were aimed at, therefore, whether its guard matched the institution's outline of lusophone culture preservation.
\end{abstract}

Resumo: Apresentamos, neste artigo, uma análise sobre o papel exercido pelo Real Gabinete Português de Leitura do Rio de Janeiro, durante a segunda metade do século XIX, no tocante à reunião e guarda de livros de ciência médica. Com a análise dos livros 
que compõem o Catálogo organizado por Ramiz Galvão, publicado em 1906 (que reúne o acervo constituído pela instituição desde 0 ano de 1837), objetivamos compreender qual era a importância relativa do acervo de ciência médica identificado em meio ao acervo geral do Real Gabinete Português de Leitura, e se esse era atualizado e relevante mediante 0 contexto de constituição do campo médico-científico no Brasil. Assim como, através de seu estudo detalhado intentamos saber qual era o idioma preponderante das obras e a que público-alvo eram direcionadas, portanto, se a sua guarda coadunava com o perfil da instituição de preservação de uma cultura lusófona.

Keywords: Royal Portuguese Cabinet of Reading, History of books and Reading, Medical history.

Palavras-chave: Real Gabinete Português de Leitura, História do livro e da leitura, História da medicina.

\section{Introduction}

Since the Court moved to Rio de Janeiro, in 1808, a cultural/scientific institutional apparatus began in the city, with the original intention of reconstructing the Lisbon cosmopolitan environment within the new realm. The first actions in this regard were represented by the creation - by decree - of institutions such as the Royal Library ${ }^{1}$, the Royal Garden ${ }^{2}$ and the School of Anatomy, Surgery and Medicine of Rio de

\footnotetext{
${ }^{1}$ Created by a D. João Royal Decree in 1810, later in 1822 the name was changed to Empire and Public Library, and after that, in 1876, National Library. See: SCHWARCZ, Lilia Moritz. A longa viagem da biblioteca dos reis: do terremoto de Lisboa à independência do Brasil. São Paulo: Companhia das Letras, 2002; BETTIOL, Maria Regina Barcelos. A fundação da Biblioteca Nacional: uma memória compartilhada entre dois mundos. Instituto Histórico e Geográfico do Rio Grande do Sul. Available at:< http://www.ingrgs.org.br/artigos/contibuicoes/M aria\%20R.\%20B.\%20Bettiol\%20-

\%20A\%20Funda\%C3\%A7\%C3\%A30\%20da\%20Biblioteca\% 20Nacional.pdf >. Accessed in: 12/15/2016.

2 Designations: Royal Garden (1808); Royal Botanical Garden (1818); Rodrigo de Freitas Lagoon Botanical Garden (1825); Botanical Garden (1833); Rio de Janeiro Botanical Garden; Rio de Janeiro Botanical Garden Research Institute (1998). Source: Horto Real. Dicionário Histórico-Biográfico das Ciências da Saúde no Brasil (1832-1930). Available at: $<$ http://www.dichistoriasaude.coc.fiocruz.br/iah/pt/verbetes/jbotri.htm>. Accessed in: 12/15/2015. About this topic, see also: DOM INGUES, Heloísa Maria Bertol. 0 J ardim Botânico do Rio de Janeiro. In: DANTES, Maria Amélia Mascarenhas (org.). Espaços da Ciência no Brasil. 1800-1930. Rio de Janeiro: Ed. Fiocruz, 2001, p. $27-56$.
} 
Janeiro3 ${ }^{3}$ all of them in the same year of the arrival of the Royal Family. Such effort would be extended and intensified in the capital in the subsequent years, with the establishment, in 1818, of the Royal Museum, as declared by D. João VI, and by transforming the Medical School into the Medical College of Rio de Janeiro. Other specific initiatives were also relevant during the process of establishing a cultural institutional apparatus in Rio de Janeiro, in the period before and after the Independence, amongst which we emphasize: the Brazilian Historical and Geographical Institute (1838), the "Germania" Association Library (1821), the British Cabinet of Reading (1826), the Royal Portuguese Cabinet of Reading (1837), the Fluminense Library (1847) and the Fluminense Imperial Typographical Association Library (1854), just to name a few of those ventures.

As highlighted by DeNipoti ${ }^{4}$, such initiatives were mainly related to a broader process of definition of National Identity, which should be connected to an idea of western civilization, well-informed by the notion of progress. Therefore, according to the author, the libraries would have the function of being the "redeemers" of a society in the process of modernization of its public spaces ${ }^{5}$, since, based on the documentation, they scoured a form of civilization, whilst aiming to delineate the social roles.

Other cultural/commercial undertaking, since the end of the $1820 \mathrm{~s}$ and beginning of the $30 \mathrm{~s}$, did also provide - to the literate people residing or visiting the city - access to books and newspapers/magazines of different origins at an "affordable"

\footnotetext{
${ }^{3}$ Designations: School of Anatomy, Surgery and Medicine of Rio de Janeiro (1808); Medical-Surgical Academy of Rio de Janeiro (1813); Medical College of Rio de Janeiro (1832); Medicine and Pharmacy College of Rio de Janeiro (1891); M edical College of Rio de Janeiro (1901); Medical Collage of the Rio de Janeiro University (1920); National Medical Collage of the University of Brazil (1937); M edical College of the Federal University of Rio de Janeiro (1965). Source: Escola Anatômica, Cirúrgica e médica do Rio de Janeiro. Dicionário Histórico-Biográfico das Ciências da Saúde no Brasil (1832-1930). Available at: < http://www.dichistoriasaude.coc.fiocruz.br/iah/pt/verbetes/escancimerj.htm>. Accessed in: 12/15/2015. About this topic, see also: DANTES, Maria Amélia Marcarenhas. Fases da implantação da ciência no Brasil. Quipu, México, v. 5, n. 2, 1988, p. 265-275; FERREIRA, Luiz Antonio;. FONSECA, Maria Rachel Fróes da; EDLER, Flavio Coelho. A Faculdade de M edicina do Rio de Janeiro no Século XIX: a organização institucional e os modelos de ensino. In: DANTES, Maria Amélia Mascarenhas (org.). Espaços da ciência no Brasil. 1800-1930. Rio de J aneiro: Ed. Fiocruz, 2001, p. 59-79.

${ }^{4}$ DENIPOTI, Cláudio. Normas e gestualidades da leitura em bibliotecas brasileiras do século XIX. Cultura Revista de História e Teoria das Ideias, v. 25, 2008.

${ }^{5}$ About the process of composition of public spaces in Brazil, in the first half of the 19th Century, see: MOREL, Marco. As transformações dos espaços públicos: imprensa, atores políticos e sociabilidades na cidade imperial (1820-1840). São Paulo: Hucitec, 2005.
} 
price, including: The Portuguese and French Cabinet of Mongie ${ }^{6}$, the Portuguese and French Cabinet of Crémière ${ }^{7}$, the French Cabinet of Dujardin ${ }^{8}$, the Portuguese and French Cabinet of Piacentini ${ }^{9}$, among others. Such offices were similar to the traditional English and French Reading Cabinets, with the common feature of being spaces with commercial and cultural characteristics at the same time, since they enabled the subscribers to read and/or rent books and newspapers/magazines without the need to purchase $\mathrm{e}^{10}$. According to Soares, the first "circulating libraries" established in Rio de Janeiro, belonging to French owners, date back from the first half of the 19th century, being the Casa do Livro Azull ${ }^{11}$ one of the best-known, from 1828 to 1852, where clients could purchase, exchange or rent books by paying a fee of "80 réis a day and 2,000 réis a month ${ }^{12}$.

In the middle of the century, according to Alessandra El Far, while a wellmaintained edition of Garnier or the Laemmert brothers would cost between 3 and 5 thousand réis (varying according to the number of pages and genre), the works from Livraria do Povo (paperback) ranged from 100 to 2 thousand réis. By contrast, a specialized worker would earn, on average, 3,300 réis a day, while a worker without specialization would receive 1,400 réis; and the payment for public servants ranged

\footnotetext{
${ }^{6}$ Louis Mongie was the owner of the main bookstore at Rua do Ouvidor, according to J oaquim Manoel de Macedo, having worked in this street, number 91 (and then renumbered to 87), from 1832 up to his death in 1853. Mongie would also own the second bookstore in Rio de Janeiro which presented a reading cabinet. In: HALLEWELL, Laurence. O livro no Brasil: sua história. São Paulo: Edusp, 2005, p. 153.

${ }^{7}$ With the auction made by Carlos Taniere, from the Reading Cabinet of J ustino Vitor Crémière (located at his residence at Rua da Alfândega, 135), after the death of the owner, in October 2nd, 1851, we can have an idea of a business of this nature. Among the auctioned assets which were acquired by Eduardo Augusto Ribeiro and Henrique da Luz Ayres, who kept the cabinet opened, there were: "a reading cabinet with books in Portuguese, French, Spanish and English, dramas and novels in paperback, 2 counters, 3 window panes, 1 writing desk, shelves and closets" (Jornal do Commercio,10.02.1851, p. 3), and also a typographer (sold bundled).

8 Désiré Dujardin French-Belgian Bookstore, located at Rua do Ouvidor, 105. Source: Almanak Administrativo, mercantil e Industrial do Rio de Janeiro, do ano de 1850. Available at: <memoria.bn.br>. Accessed in 12/15/2015.

${ }^{9}$ J oaquim Antonio Piacentini. Source: Almanak Administrativo, mercantil e Industrial do Rio de Janeiro.

10 SOARES, Maria Angélica Lau Pereira. Visão da modernidade. A presença britânica no Gabinete de leitura (1837-1838). Dissertação (M estrado em Estudos linguísticos e literários em inglês). São Paulo: Universidade de São Paulo, 2006.

${ }^{11}$ Casa do Livro Azul worked from 1828 to 1852 , being the most popular second-hand bookstore at Rua do Ouvidor, selling, purchasing, exchanging and renting books, and also receiving some new books as payment. The owner was a French man named Albin Jourdan (Brazilianised to Albino Jordão). Source: HALLEWELL, Laurence. Op. Cit., p. 127. The books in Portuguese were always highlighted in the advertisement of Casa do Livro Azul (located at Rua do Ouvidor, 121) and, in the several advertisements published in the pages of Jornal do Commercio, up to December 24th, 1851, they emphasized the books written in Portuguese or translated into Portuguese about Commerce, Law, History, Philosophy and Medicine, besides romances and novels.

${ }^{12}$ J ornal do Commercio, 23/12/1835 Apud SOARES, Op. Cit. p. 20.
} 
from 60 thousand réis to 100 thousand réis a month ${ }^{13}$. Such figures confirm that there was, among the small population of literates in the Court, a significant share of potential book buyers or renters, justified the increasing presence of that kind of institutions in the city, throughout the nineteenth century.

Furthermore, both because it added a significant portion of consumers of printed material and because it acted as an economic center of the country, the capital would be consolidated, throughout the 19th century, as main entry port of printed material of the Empire, and also there were in the City the largest number of booksellers, editors and book merchants of the whole country ${ }^{14}$. The main streets in the city center would gradually start to be populated by a large selection of printed material, sold by the book merchants who offered all sorts of literary genre, making it difficult for the reader to go home empty-handed, as stated by Alessandra El Farr ${ }^{15}$, considering the large selection of books for every taste and budget.

It is important to stress that this commerce would be motivated, mostly, by the concentration of an intellectual and political elite in Rio de Janeiro, whose driving force was in the centralization of the imperial bureaucracy in the city, as in the existence of institutions such as the Rio de Janeiro School of M edicine, responsible for the formation of many sons of the political, economical and cultural elite of the Empire.

For those who do not have a significant monthly sum to purchase books in the renowned bookshelves at Rua do Ouvidor, it was possible to buy second-hand books in bookstores located in the neighboring streets, or even exchange or rent printed material at low cost in the "circulating libraries" or reading cabinets, with commercial intent. For those who had a reasonable amount of money, it would be possible to join the cabinets initially formed by groups of expatriates with the Portuguese Cabinet of

\footnotetext{
${ }^{13}$ EL FAR, Alessandra. Ao gosto do povo: as edições baratíssimas de finais do século XIX. In: BRAGANÇA, Aníbal; ABREU, Márcia (orgs.). Impresso no Brasil: dois séculos de livros brasileiros. São Paulo: Editora Unesp, 2010, p. 89-99.

${ }^{14}$ See: FERREIRA, Tânia Maria Tavares Bessone da Cruz. Palácios de destinos cruzados: bibliotecas, homens e livros no Rio de Janeiro (1870-1920). Rio de Janeiro: Arquivo Nacional, 1997; HALLEWELL, Laurence. Op. cit., BRAGANÇA, Aníbal; ABREU, Márcia (orgs.). Impresso no Brasil. São Paulo: Ed. Unesp, 2010; GONÇALVES, Monique de Siqueira. Livros, teses e periódicos médicos na construção do conhecimento médico sobre as doenças nervosas na Corte Imperial (1850-1880). In: FERREIRA, Tania B. C; RIBEIRO, Gladys S.; GONÇALVES, M onique de S. (orgs.). 0 Oitocentos entre livros, livreiros, impressos missivas e bibliotecas. São Paulo: Alameda, 2013, p. 59-87.

${ }^{15}$ EL FAR, Alessandra. Páginas de sensação. Literatura popular e pornográfica no Rio de Janeiro (18701924). São Paulo: Companhia das Letras, 2004.
} 
Reading ${ }^{16}$, the "Germania" Association Library and the British Cabinet of Reading. Moreover, there was the possibility of accessing the desired books through Public Libraries, such as the National Library, the Fluminense Library, or even through specialized libraries, as the example of the Medicine College, Polytechnic School, Army and Navy libraries.

In the second half of the 19th century, the literates in the country could find in libraries, commercial reading cabinets, associations and public libraries, sociability environments, where the love for reading would confer a high status to the frequenters, in a society highly hierarchical. The typography and newsrooms also fulfilled this role (along with locations such as cafeterias and drugstores), grouping literate men who, within those spaces, were included in closed customer networks, in order to obtain prestige by narrowing emotional, political and professional ties with the other frequenters ${ }^{17}$.

Broadly, we believe that the institutional initiatives put into practice progressively, but in a discontinuous and not ordered manner - whether by the State or by groups and/or individuals belonging to civil society - occurred to set in the city of Rio de Janeiro, as a capital, a cultural institutional apparatus, providing to the small literate portion of the population, access to varied and updated readings about on diverse subjects ${ }^{18}$. Medical science was, thus, one of the preferential topics covered by those collections, according to researches we have made, mainly because the first Medicine College of the Empire (created in 1808) was established in the city and the students needed alternative means to obtain the necessary skills to their formation, considering the high price of the books.

\footnotetext{
${ }^{16}$ In the pages of the Almanak Laemmert from 1850 to 1873 the Portuguese Cabinet of Reading announces that the annuity would be 12 thousand réis, and there was still the option, from the end of the 1860s, to pay 7 thousand réis for six months. The amount of 12 thousand réis annually was the same as charged to the members of the Fluminense Library.

${ }^{17}$ FERREIRA, Tania Maria Tavares Bessone da Cruz. As bibliotecas públicas cariocas no século XIX. In: INTERCOM, $2011 . \quad$ Available at: http://www.intercom.org.br/papers/nacionais/2001/papers/NP4FERREIRA.pdf. Accessed in: 6/20/2013. . 0 que liam os cariocas no século XIX? In: XXVIII Congresso Brasileiro de Ciências da Comunicação, $2005 . \quad$ Available at: http://galaxy.intercom.org.br:8180/dspace/bitstream/1904/17536/1/R2053-1.pdf. Accessed in: 6/2/2011.

${ }^{18}$ About this topic, see also: GONÇALVES, Monique de Siqueira. Livros de ciência médica na Biblioteca Nacional: 0 acervo sobre as doenças nervosas (1860-1880). História Unisinos, 18, 1, 2014, p. 146-157.
} 
Another reason for incrementing the collection referred to Medicine would be the growing demand for popular medicine manuals ${ }^{19}$ - which appeared in Brazil in the first half of the 19th century and were intensified from the 1850s, due to the burst of yellow fever and cholera epidemic outbreaks -, because they allowed the selftreatment and medical therapy of relatives, households and even slaves serving the family ${ }^{20}$.

Thus, we have tried to present the considerations about the role of the Royal Portuguese Cabinet of Reading in a context of construction and expansion of a cultural/scientific apparatus in the city of Rio de Janeiro, emphasizing the collection related to medical science found in the catalogs of such institution which, if in the middle of the century had around 16 thousand volumes, at the end of the Empire already had a collection estimated in 50 thousand volumes, included among the main Empire Libraries ${ }^{21}$. Below follows the growth of the collection.

Table 1 - Collection of the Royal Portuguese Cabinet of Reading of Rio de Janeiro (1850-1881)

\begin{tabular}{|l|l|l|}
\hline Yeer & Collection & Directors \\
\hline $\mathbf{1 8 5 0}$ & Around 16,000 vol. & $\begin{array}{l}\text { Mr. Adolpho Manoel Victorino da } \\
\text { Costa }\end{array}$ \\
\hline $\mathbf{1 8 5 1}$ & Around 18,000 vol. & Idem \\
\hline $\mathbf{1 8 5 2}$ & Around 20,000 vol. & Idem \\
\hline $\mathbf{1 8 5 3}$ & Around 22,000 vol. & Idem \\
\hline $\mathbf{1 8 5 4}$ & Around 25,000 vol. & Idem \\
\hline $\mathbf{1 8 5 5}$ & Around 27,000 vol. & João Henrique Ulrich \\
\hline $\mathbf{1 8 5 9}$ & Around 30,000 vol. & Mr. José Pedro da Silva Camacho \\
\hline $\mathbf{1 8 6 0}$ & Around 32,000 vol. & Idem \\
\hline $\mathbf{1 8 6 1}$ & Around 32,000 vol. & José Peixoto de Faria Azevedo \\
\hline
\end{tabular}

${ }^{19}$ There were several advertisements selling medicine popular manuals in the main Court daily newspapers, such as Jornal do Commercio and Correio Mercantil.

${ }^{20}$ FIGUEIREDO, Betânia Gonçalves. Os manuais de medicina e a circulação do saber no século XIX no Brasil: mediação entre o saber acadêmico e o saber popular. Educar, Curitiba, n. 25, 2005, p. 59-73.

${ }^{21}$ Only from 1850 on, the quantifications of the Royal Portuguese Cabinet of Reading collection started to be published at Laemmert Almanack. 


\begin{tabular}{|c|c|c|}
\hline 1862 & Around 32,000 vol. & Idem \\
\hline 1864 & Around 35,000 vol. & Idem \\
\hline 1865 & Around 40,000 vol. & Idem \\
\hline 1867 & $\begin{array}{l}\text { Around } 37,000 \text { vol. with } 16.500 \\
\text { works }\end{array}$ & José Pereira Soares \\
\hline 1870 & $\begin{array}{l}\text { Around } 42,000 \text { vol. with } 18.000 \\
\text { works }\end{array}$ & $\begin{array}{l}\text { Manoel José Gonçalves Machado } \\
\text { Júnior }\end{array}$ \\
\hline 1873 & $\begin{array}{l}\text { Around } 50,000 \text { vol. with } 21.000 \\
\text { works }\end{array}$ & Boaventura Gonçalves Roque \\
\hline 1874 & $\begin{array}{l}\text { Around } 50,000 \text { vol. with } 21.000 \\
\text { works }\end{array}$ & José Joaquim Ferreira Margarido \\
\hline 1875 & $\begin{array}{l}\text { Around } 50,000 \text { vol. with } 21.000 \\
\text { works }\end{array}$ & Idem \\
\hline 1876 & $\begin{array}{l}\text { Around } 50,000 \text { vol. with } 21.000 \\
\text { works }\end{array}$ & - \\
\hline 1877 & $\begin{array}{l}\text { Around } 50,000 \text { vol. with } 21.963 \\
\text { works }\end{array}$ & - \\
\hline 1879 & $\begin{array}{l}\text { Around } 50,000 \text { vol. with } 22.681 \\
\text { works }\end{array}$ & $\begin{array}{l}\text { Eduardo Rodrigues Cardoso Ramalho } \\
\text { Ortigão }\end{array}$ \\
\hline 1881 & $\begin{array}{l}\text { Around } 50,000 \text { vol. with } 23.853 \\
\text { works }\end{array}$ & \\
\hline
\end{tabular}

Source: Almanack Laemmert (1850-1881)

\section{The Royal Portuguese Cabinet of Reading of Rio de Janeiro and its Medical Sciences Collection}

The number of Portuguese people established in the entire Empire of Brazil is so substantial; and hundreds of fellow citizens go there continuously, in such a way that the press in Portugal has the obligation to share with them the attention and helpfulness to all of the future sons of this glorious homeland (...) "All the other social relationships that can be established by the newspapers between two peoples. The literary publications, the academic works, the talents initiating in Arts and Letters will be acknowledged and celebrated in the Portuguese press, and the ones in Portugal will be as well acknowledged and celebrated by the Brazilian press. Throughout the Empire, institutes created to the Portuguese, deserving to be more popular among us, such as the Cabinet of Reading of 
Rio de Janeiro and Pernambuco, the hospital recently established in the same city and other associations proving the fraternity and harmony existing among our compatriots, who, through this coexistence, alleviates the homesick feeling (..... ${ }^{22}$

The Portuguese Cabinet of Reading was founded in May 1837 by an association of Portuguese emigrants residing in the city of Rio de Janeiro. According to Schapochnik ${ }^{23}$, the process of creation of the collection of this institution was based on its identity character, since it was organized as a space for safekeeping the national memory. Furthermore, as highlighted by Azevedo ${ }^{24}$, the Portuguese emigrated arriving in Rio de Janeiro during the 19th century found few places to read what was published in their country, because of a Gallicism reducing the space of the Portuguese culture from the reading spaces. This aspect should certainly result from the existence of a strong Anti-Portuguese sentiment in the city of Rio de Janeiro, startled during the period before and after the Independence of Brazil ${ }^{25}$.

The strengthening of the language identity would also permeate, thus, according to Azevedo ${ }^{26}$, the creation of association libraries, such as the Portuguese Cabinet of Reading of Rio de Janeiro, acting as a social space for the citizens speaking the same language and living in the capital. Thus, the consolidation of a identity character of the Portuguese culture in the creation of the collection intended to consolidate the ideals to maintain the Portuguese memory.

In regard to the rich collection of Medical Sciences existing in the Cabinet and surveyed by the reading of the catalog 27 elaborated and published by the librarian Ramiz Galvão ${ }^{28}$, in 1906, we could identify the existence of a substantial quantity of

\footnotetext{
22 Transcripts. Colonisation. Correio M ercantil, 7/7/1856, p. 2.

${ }^{23}$ SCHAPOCHNIK, Nelson. Os jardins das delícias: gabinetes literários, bibliotecas e figurações da leitura na corte imperial. 1999. Tese (Doutorado em História). São Paulo: Universidade de São Paulo, 1999.

${ }^{24}$ AZEVEDO, Fabiano Cataldo. Contributo para traçar o perfil do público leitor do Real Gabinete Português de Leitura: 1837-1847. Ci. Inf., v. 37, n.2, 2008, p 20-31.

${ }^{25}$ RIBEIRO, Gladys Sabina. A liberdade em construção: identidade nacional e conflitos antilusitanos no Primeiro Reinado. Tese (Doutorado em História). Campinas: Unicamp, 1997.

${ }^{26}$ AZEVEDO, Fabiano Cataldo. 0 acervo bibliográfico do Gabinete Português de leitura como lugar de memória e forma reconhecível: considerações acerca dessas aproximações. Convergência Lusíada, n. 25, 2011, p. 43-60.

${ }_{27}$ GALVÃO, Benjamin Franklin Ramiz Galvão (Org.). Catálogo do Gabinete Português de Leitura no Rio de Janeiro. Rio de Janeiro: Typ. do Jornal do Commercio de Rodrigues \& C., 1906.

${ }^{28}$ Benjamin Franklin Ramiz Galvão - Bachelor of Arts degree at Colégio Pedro II, medical doctor at the College of Rio de Janeiro, was nominated as librarian of the National Library in 1870, substitute lecturer of the section of ancillary sciences of the Medicine College in 1871 and professor of Botanic in 1881. In 1882 he had been chosen by the Emperor to be the preceptor of the children of Princess Isabel, being
} 
works in Portuguese, French and English. Such aspect differed significantly from the collection about the same theme existing in the main public library of Rio de Janeiro, National Library. In it, the massive existence of French works not only confirmed the said "Gallicism"29 but also reflected the prominence of the French Medicine in the Nineteenth Century, mainly in relation to orthopathy, in the intellectual environment of the physicians from Rio de Janeiro ${ }^{30}$.

In the 1906 catalog - containing the works acquired by purchase or donation since the foundation of the Portuguese Cabinet of Reading - we calculated 2,183 works regarding Medicine ${ }^{31}$, and among them many editions published by printing companies in Rio de Janeiro, from Lisbon and London, written by Brazilian, Portuguese or English doctors, respectively. Despite the existence of a significant amount of books in French - among which 533 books were identified - such works represented only around $1 / 4$ of the general collection about Medicine in the institution, what, as already highlighted, differed from the profile of the collection of other Public Libraries, where French works were prevalent.

In comparison to the collection of Medical Sciences computed in the Catalog of books from the Cabinet, published in 1858, we may deduce that during the second half of the 19th century this collection acquired its relevance in terms of numbers. In the catalog of 1858 only 211 medicine books were listed, with 86 books in French, 68 in Portuguese, 47 in Latin, 6 in English and 4 in Spanish. Among them, 136 had been published in the 19th century, and that would denote the commitment of the administrators to acquire updated books, that could be referred to by the Cabinet readers. Such quantum leap, from 211 to 2,183 works of medical sciences, denotes the effort of the Cabinet members to increase the collection of the institution in relation to the health topic ${ }^{32}$.

retired from both positions (source: BLAKE, Augusto Victorino Alves Sacramento. Diccionario bibliographico brasileiro. $1^{\circ}$ volume. Rio de Janeiro: Typographia Nacional, 1883, p. 395).

${ }^{29}$ In the 19th century, Brazil had a strong influence of the French culture, so the reading habits were also strongly influenced by this prevalence, given the importance granted to the ideas arising from the words of the French intellectuals. The intensity in which French books circulated in Rio de Janeiro was, especially, through a blatant presence of typographers and booksellers in the city, since the beginning of the 19th century. About this topic: M OREL, M arco. Op. Cit., 2005; HALLEWELL, Lawrence. Op. Cit., 2005.

${ }^{30}$ GONÇALVES, M onique de Siqueira. Op. Cit., 2014.

${ }^{31}$ The total quantity of the volumes is not specified.

${ }^{32}$ Catalog of the Cabinet books. Rio de Janeiro, 1858. 
The themes of the books, thesis, memoirs ${ }^{33}$, reports, speeches, printed letters and newspapers, either national and international, belonging to the collection were well-diversified, including, among them: medical practice, anatomy, physiology, experimental medicine, digestion, lymphatic system, optical physiology, hygiene, popular hygiene, public hygiene, military/maritime hygiene, hygiene in hot countries, climatology, homeopathy, nutrition, waters, poisons, prostitution, medicine history, drugs falsification, wine, medical geography, therapeutics, pharmacy (including journals, pharmacopoeia, therapeutics, books of pharmacy history), medical pathology, childcare, clinical microscopy, specific diseases (such as yellow fever, cholera, tuberculosis, bronchitis gout), dermatology, venereal diseases, operative/surgical medicine, entozoon, ophthalmology, among others. Those topics were deduced by analyzing the material, since there was no explicit separation into themes or subjects in the catalog, and they were implied in the titles placement.

Besides the works listed in the subclass "Medicine" (belonging to Class VI Applied Sciences), the works related to physiology and mental hygiene, as well as works related to psychiatric pathologies featured the Catalog arranged by Ramiz Galvão, within "Class I - Philosophy", subclass "Spirit and Body", alongside other classifications, such as: "Hallucinations. Magic, Divination. Occultism and Spiritism", "Animal magnetism. Hypnotism"; "Sleep. Dreams. Sleepwalking", "Mental Characteristics", "Moods", "Physiognomy" and "Phrenology". Within this Class there were the following subclasses: "General Philosophy", "Metaphysics ", "Metaphysical Issues", "Philosophical Systems", "Psychology ", "Logic", "Ethics", "Ancient Philosophers" and "Modern Philosophers". They were classified apart from the works related to medical sciences contained in Class VI - "Applied Sciences. Technology", bringing together the following subclasses: "Medicine", "Useful Arts", "Engineering", "Agriculture", "Household Economy", "Transportation. Commerce", "Chemical Industries", "Manufactures", "Mechanical Industries. Crafts" and "Construction".

Among the works classified as "Spirit and Body", there were several classic works related to mental medicine, such as: M. Bain, L'esprit et le corps considérés au point de vue de leurs rélations, 1873; Louis Büchner, Essais de Philosophie et de Science naturelle (translated from German), 1866; P. J. G. Cabanis, Rapports du physique et du

\footnotetext{
${ }^{33}$ Scientific/dissertative work focused on a medical subject area.
} 
moral de l'homme, 1824; P. Flourens, De la vie et de l'intelligence, de 1858; P. Janet, Le cerveau et la penseé, 1867; Ch. E H. Janiet, De la vie et de son interprétation dans les diférents ages de l'humanité, 1860; Lélut, Physiologie de la pensée. Recherche critique des rapports $d u$ corps a l'espirit, 1852; Maine de Biran, Nouvelles considérations sur les rapports du physique et du moral de l'homme (posthumously published by Victor Cousin), 1851; E. Billod, Des maladies mentales et nerveuses. Pathologie, medicine legale, administration des asiles d'aliénés, 1882; M. Bra, Manuel des maladies mentales, 1883; E. Esquirol, Des maladies mentales considérées sous les rapports médical, hygiénique et médico-légal, 1838; H. Maudsley, The Physiologie and pathology of mind, 1868; J. Moreau, La psychologie morbide dans ses rapports avec la philosophie de I'histoire ou de l'influence des névropathies sur le dynamisme intellectuel, 1859; C. Ollivier, Influence des affections organiques sur la raison ou pathologie morale, 1867; $E$, Regis, Manuel pratique de medicine mentale, 1885; A. Voisin, Leçons cliniques sur les maladies mentales et sur les maladies nerveuses profesées à Salpêtrière, 1883; F. E. Foderé, Traité du délire, aplique a la medicine, a la morale et a la législation, 1817; G. L. Harrison, Legislation on insanity, 1884; Ph. Pinel, Traité médico-philosophique sur I'aliénation mentale, 1809; I. Ray, A treatise on the medical jurisprudence of insanity, 1838; J. Tissot, La folie considérée surtout dans ses rapports avec la psychologie normale, 1877; G. Dumas, Les États intellectuels dans la mélancolie, 1895; A. B. de La Grandiere, De la nostalgie ou mal du pays, 1873; A. Mairet, De la démence mélancolique, 1883; Th. Ribot, Les maladies de la mémoire, 1881; L. Figuier, Histoire du merveilleux dans les temps modernes, 1869; L. Bordelon, História das imaginações extravagantes de monsieur Oufle causadas pela leitura dos livros, 1814; A. Brierre de Boismont, Des hallucionations ou histoire raisonée des apparitions, des visions, des sanges, de l'extase, du magnétisme et du somnambulisme, 1852; Gougenot des Mousseaux, Les médiateurs et les moyens de la magie, les hallucinattions et les savants, le fantome humain et le príncipe vital, 1863; F. Lélut, L'amulette de Pascal pour servir à I'histoire des hallucinations, 1846; A. M aury, Des hallucinations du mysticisme Chrétien, $\mathrm{s} / \mathrm{d}$; F. Lélut, Du démon de Socrate, specimen d'une application de la science psychologique a celle de l'histoire, 1836;

In this subclass, there were also the following books: W. Scott, Histoire de la démonologie et de la sorcelterie, 1835-36; Duroy de Bruignae, Satan de la magie de nos 
jours - Réflexions pratiques sur le magnétisme, le spiritisme et la magie, 1864; Léon Denis, 0 porquê da vida - solução racional do problema da existência (...), de 1898; Alan Kardec, L'évangelie sélon le spiritisme contenat l'explication des maximes Morales du Christ (...), 1868; Alan Kardec, 0 que é o Spiritismo e noções elementares do Spiritismo. Introdução ao conhecimento do mundo invisível pela manifestação dos espíritos (Portuguese version), 1893; A. S. M orin, Du Magnétisme et des sciences occultes, 1890, among other 125 books.

However, other works classified as related to nervous diseases featured among medicine books such as: J. M. Charcot, Leçons sur les maladies du système nerveux, 1880; R. Grenier, Des localisations dans les maladies nerveuses sans lésions appréciables, 1886; C. M. S. Sandras, Traité pratique des maladies nerveuses, 1851; A. Voisin, Leçons cliniques sur les maladies mentales et sur les maladies nerveuses, 1883; and A. Vulpian, Maladies du système nerveux, 1879, among other thirty books. This leads us to believe that the organization of the works integrated the processes of jurisdictional disputes ${ }^{34}$ existing since the last quarter of the 19th century about the formation of a psychiatric medicine in Brazil, qualifying the adoption of an organicist perspective in mental medicine, as being part of a process of scientification of psychiatry. The process occurred in contrast to the alienist practice constituted by the French and British tradition, coined between the end of the 18th century and the beginning of the 19th century. It was, thus, the inclusion made by Ramiz Galvão (as a doctor) in the preparation of a catalog, a demarcationist socio-professional perspective, in which the result of a scientific controversy - putting on opposite sides a medicine with alienist tradition (regarded as non-scientific, at the end of the dispute) and an organicist psychiatric medicine (considered scientific) - was incorporated.

Another interesting aspect of this collection, in relation to the works classified in the "Medicine" subclass, is related to the significant presence of popular manuals, which, according to Betânia Figueired ${ }^{35}$, played the role of cultural mediator between the medical and popular knowledge. The daily use of such books (with wide circulation, several reprints and intense circulation in Brazil during the 19th century), by people

${ }^{34}$ Concept developed by Andrew Abbott (1998) to analyze the process of socio-professional disputes permeating the mental medicine in the 19th century. See: ABBOT, Andrew. The systems of professions. An essay on the division of expert labor. Chicago and London: The University of Chicago Press, 1998.

${ }^{35}$ FIGUEIREDO, Op. Cit., 2005. 
with or without academic background, played a fundamental role in a society lacking doctors, needed in most of the territory. Furthermore, the process of transferring health care to specialists who, gradually, gained social legitimacy and distinguished from the other practitioners or healers was in progress, and they were looking for a socioprofessional legitimization ${ }^{36}$. Therefore, we believe the major presence of works to disseminate/mainstream the scientific area in the collection was related to the target audience of the Cabinet, who were notably educated people, linguistically competent, but not specialized in medical sciences.

In that subject area, featured the renowned works of Luiz Napoleão Chernoviz, Dicionário de Medicina Popular ${ }^{37}$ (printed in Paris, in Portuguese); J. B. A. Imbert, Manual do fazendeiro, ou tratado doméstico sobre as enfermidades dos negros (edited in Rio de Janeiro with issues in 1834 and 1839); and J. B. Dazille, Observações sobre as enfermidades dos negros, suas causas, seus tratamentos e meios de prevenir (edited in Portugal, at Arco do Cego typography, 1801). It is worth to highlight that the reference to the last two books were succeeded by the observations that such works could not leave the institution. This also indicates the strong demand for those manuals, because only books considered rare had such restriction ${ }^{38}$.

We also identified other seven scientific diffusion books written by foreign authors (published in Portuguese by national or foreigner printing companies), such as: Cazenave, Manual de medicina prática para uso das famílias, Paris (1886); Levy, Guia de higiene e saúde para facilitar os socorros em caso de acidentes ou de moléstias, 1900; Jean François Macé, História de um bocadinho de pão - Cartas a uma menina acerca da vida do homem e dos animais, undated; Chidloe, Homeopatia doméstica ou Instruções para qualquer pessoa poder curar homeopaticamente nos lugares onde não há médicos, (1853); Gouré, A homeopatia posta ao alcance de todos (1850); Benoît Mure, A prática elementar da homeopatia,(1855-56); Benoît Mure, 0 médico do povo (1868).

In addition to such manuals, we highlight eleven books by Portuguese authors in this category (ten edited in Lisbon and one in Porto), namely: Cardoso Klerl,

\footnotetext{
${ }^{36}$ PIM ENTA, Tânia Salgado. 0 exercício das artes de curar no Rio de Janeiro (1828-1855). Tese (Doutorado em História). São Paulo: UNICAM P, 2003.

${ }^{37}$ The book titles, in Portuguese, were updated according to the current standards of Portuguese, but the proper names were kept as they used to be written.

${ }^{38}$ We reached this conclusion because, as the catalog was created in the beginning of the 19th century, such works would not be considered rare at that moment.
} 
Formulário geral médico cirúrgico, ou guia prático do médico, do cirurgião e do farmacêutico (1842); Costa Paiva, Aforismos de medicina e cirurgia práticas (1837); Julio Arthur Lopes Cardoso, A medicina nos casos urgentes (1888); Julio Arthur Lopes Cardoso, Manual do enfermeiro (1889); M. R. d'Oliveira, Medicina doméstica (1883); Ayres B. Pinto, Guia médico-homeopático familiar ou modo de cada uma se tratar pronta e suavemente das moléstias mais comuns (1870); Francisco Soares da Ribera, Cirurgia metódica e química reformada (1721); Filipe José Rodrigues, Dicionário homeopático portátil de sintoma (1858); J. P. Almeida Brandão, 0 livro das famílias ou instruções acerca do matrimônio e das doenças mais comuns (1873); Antonio José de Sousa Pinto, Medicina política ou princípios necessários tanto aos professores como úteis aos enfermos (1822); and Manoel J oaquim Henriques de Paiva, Curso de medicina teórica e prática, destinado para os cirurgiões que andam embarcados, ou que não estudaram nas universidades (1792). Presence to strengthen the Cabinet effort to establish a collection which could be a reference in relation to the works of Portuguese authors, as most part of those books were not in the catalog of other libraries of the city.

Other outstanding characteristic of such collection is the safekeeping of books about homeopathic medicine, and during the second half of the 19th century, the homeopathy enthusiasts have made great efforts to disclose its principles, and gained notoriety among the Court society, through the translation and sale of the books of Mure ${ }^{39}$, among others. Furthermore, the translation of such books denotes, in our opinion, an aspect presented by Figueiredo ${ }^{40}$ that the Portuguese edition aimed the professional acknowledgment and fortune, given the intense circulation of such books across the territory

The existence of a representative collection about homeopathy in the Cabinet was related to the practice of homeopathic doctors in such institution, as the first

\footnotetext{
39 Benoit-Jules Mure (1809-1858) was considered one of the introducers and great motivator of homeopathy in Brazil. Medical doctor graduated by Montpellier College, he practiced homeopathy in Europe and came to Brazil in 1840. In the next year he tried to establish a colonization project with French Socialist orientation, at Saí (Santa Catarina), where he started to organize the Supplementary Medicine College and Homeopathic Institute of Saí (1842). As the project failed, he was transferred to Rio de Janeiro in 1843, where he founded the Homeopathic Institute of Brazil, of which he was the president up to 1848, when he returned to Europe. Source: Instituto Homeopático do Brasil. Dicionário Histórico-Biográfico das Ciências da Saúde no Brasil (1832-1930). Available at: <http://www.dichistoriasaude.coc.fiocruz.br/iah/pt/pdf/insthombr.pdf>. Accessed in: 12/28/2015.

${ }^{40}$ FIGUEIREDO, Op. Cit., 2005.
} 
librarian, Dr. José d'Almeida e Silva ${ }^{41}$. A theoretical influence that, despite being rejected by most of the medical class belonging to the Court medical elite ${ }^{42}$, had many followers, mainly after the first great yellow fever epidemic in the city - after the introduction of homeopathy in Brazil -, represented by the French doctor Benoit Jules Mure. Such characteristic was present in the National Library, reflecting the interest of the medical class, and a significant amount of the population, in the infinitesimal homeopathic formulations.

We also identified other books not intended to the specialized audience in English, French, Italian and Spanish, emphasizing the English editions, such as: G. H. Barkow, A manual of the practice of medicine (1856); Thomas Graham, Modern domestic medicine (1853); James Copland, A dictionary of pratical medicine (1866) and Edmund A. Parkes, A manual of practical hygiene, among others ${ }^{43}$. Such works came from a donation made by a pharmacist graduated in sciences in Brussels during the 1860s, and known for his practice in the Imperial Court, Antonio Alves Ferreira ${ }^{44}$.

According to Azevedo ${ }^{45}$, the collection donated by Alves Ferreira was composed by 1,400 copies of which we could identify 298 books ${ }^{46}$ classified as "Medicine"47. Among them, 134 were in English (115 edited in London, 7 in Dublin/Edinburgh and 12 in the United States), 125 in French, 12 in Portuguese (5 edited in Brazil and 7 in Portugal), 6 in Italian, 1 in German and 1 in Spanish. Despite this collection presented works about general medicine matters, such as clinical practice, anatomy, experimental medicine and hygiene (among others), there was a concentration of works about therapeutics and/or pharmacology, history of pharmacy, counterfeiting of medicines,

\footnotetext{
${ }^{41}$ Little information appear in the bibliographical dictionary prepared by Sacramento Blake about this character. Blake only stated he was a voluntary practitioner from Minas Gerais, Brazilian, with his name included in the Catalog of the Brazilian Medical Exposure in 1883, as the Author of the book: Resumo da medicina prática, edited in 1848. (BLAKE, Op. Cit., vol. 4, p. 274)

${ }^{42}$ The medical elite is not necessarily made up by the best doctors, but by those who traditionally concentrate different types of professional influence. See the concept of medical elite in the Weisz article. Les transformations de l"Elite medicale em France. Actes de la Recherche en Sciences Sociales, no 74, p. 33-46, sept. 1988.

${ }^{43}$ Such names reflect a small sample.

44 VELLOSO, Verônica Pimenta. Farmácia na Corte Imperial (1851-1887): práticas e saberes. Tese (Doutorado em História das Ciências). Rio de Janeiro: Casa de Oswaldo Cruz/Fiocruz, 2007.

${ }^{45}$ AZEVEDO, Fabiano Cataldo. A doação da biblioteca J oão do Rio ao Real Gabinete Português de Leitura: aspectos de uma histórica pouco conhecida. Perspectivas em ciência da informação, v. 15, n. 3, set./dez. 2010, p. 233-249.

${ }^{46}$ The quantity of books is larger, because many books had more than one volume and, with they were donated with pharmacy newspapers collections with several issues. Additionally, some of the works were not identified and the number may include inaccuracies, since it was made by title.

${ }^{47}$ In the collection there were several works that were not about medicine or pharmacy.
} 
besides a great variety of pharmacopoeias and pharmacy journals, with an eminently practical character of the library created. This aspect may be confirmed by the prominence of books edited in the 60s (comprising 94 titles), followed by 53 books from the 1870s, 44 from the 1850s, 33 from the 1820s, 16 from the 1880s and, finally, 10 from the 1830s, besides other books without a specified date. That means that it was not a library with classic books, it included books related to their area of expertise and everyday practice. This data confirms our assumption that there was, among the doctors in the Court, an intense circulation of scientific ideas coming from different knowledge production centers, resulting of an effort of continuous update by the intellectual physicians. Such readings, made through the acquisition of books and journals with the intention to inform them about everything that was created overseas, with such knowledge being adopted and receiving another meaning in the daily practice. Nonetheless, it is of utmost importance to highlight that the significant presence of books in English within the Cabinet collection, as opposed to the profile of the other libraries in Rio de Janeiro during the 19th century resulted mainly from the donation of Alves Ferreira, and the works were not acquired through purchase, and, consequently, it was not a result of a "policy" of books acquisition.

Thus, despite a strong presence of works in English in the Cabinet, the quantity of books in French was significant, including authors commonly adopted in the national medical literature, such as: A. Bouchardat, Le travail. Son influence sur la santé (1863); Broussais, Examen des doctrines médicales et des système de Nosologie (182934); A. Becquerel, Traité élémentaire d'Hygiene privée et publique (1864); Sandras, C. M. S., Traité pratique des maladies nerveuses (1851); Lélut, De la santé du peuple (1849); Claude Bernard, Rapport sur les progrès et la marche de la physiologie génerale em France (1867); A. Armand, Médicine et hygiène des pays chauds et spécialement de l'Algérie et des colonies (1853); e E. Bouchut, Dictionnaire de Thérapeutique médicale et chirurgicale (1867), among many others.

The three last books also figured the largest collection donated to the Cabinet during the 19th century - with 5,628 volumes, according to Azevedo $0^{48}$-, by the Portuguese citizen Francisco Manuel de Mello (who had also been a librarian in the

${ }^{48}$ AZEVEDO, Op. Cit., 2010. 
Cabinet). Of this amount, we identified 139 volumes ${ }^{49}$ related to the category "Medicine", among other works listed under the following subject areas: "Psychology", "Spirit and Body" and "Metaphysics and Philosophy"50. Amongst the books about medicine, 77 were in French, 58 in Portuguese (36 of which were edited in Portugal and 19 in Brazil), 1 in German and 1 in Latin. Despite the books listed under the heading "Medicine" were the smaller portion of his donation, they were significant, as the collection belonged to an individual with no background in Medicine. Besides works to mainstream Medicine, such as Dicionario de medicina popular (1862), by Pedro Luiz Napoleão Chernoviz, there were also works about homeopathy, like Médico do povo (1868), by Benoit Mure, and some national productions such as the book written by Joaquim Remédios Monteiro dos Santos, Hygiene e educação da infância (1868). The collection also had classic books from the French Medicine, such as Th. Ribot, Les maladies de la mémoire (1881); and La folie considérée surtout dans ses rapports avec la psychologie normale, J. Tissot (1877).

In the collection coming from Manuel de Mello we also found a great variety of subject areas, such as medical practice, hygiene in hot countries, history of medicine, histology, popular hygiene, military/maritime hygiene, childcare, sanitation, therapeutics. However, there was a focus of titles about homeopathy, physiology and venereal diseases. On the whole, the titles were connected to the main diseases and health problems faced by the Brazilian inhabitants, highlighting that the books also enabled the individuals with no background in Medicine to obtain knowledge about what was being produced in this field. The books were updated, being mainly edited in the 1860s (with a total of 74 books), followed by 25 edited in the 1850s, 16 edited in the 1870s, 5 edited in the 1830s, 3 edited in the 1880s, 3 edited in the 1840s, 1 edited in the 1820 s, and others undated, including a rare edition of 1237 , written by J. de Vigo, about surgery.

However, when analyzing the medicine collection purchased by or donated to the Cabinet, from 1837 to 1906, we can observe a great effort to compile (original or translated) works in Portuguese, as they were the vast majority of it, with 1,263 books (of which 1088 had been edited in Brazil, 173 in Portugal and 2 in Goa). Besides books written by Portuguese authors - in a greater amount in this collection in comparison

\footnotetext{
${ }^{49}$ As the collection mentioned before, such number do not represent the total number of volumes.

${ }^{50}$ There is no survey for the whole collection.
} 
to other collections of public libraries in the city - as the books by Julio Arthur Lopes Cardoso, A medicina nos casos urgentes (1888) and Manual do enfermeiro (1889); there were also medical science newspapers printed in Lisbon, such as Jornal de Sciencias Medicas de Lisboa (1835-64) or A M edicina M oderna (1899-1905), edited in Porto. This supports the perspective advocated by Schapochnik ${ }^{51}$ and Azevedo, that such collection had been created to consolidate a Portuguese memory in the former Portuguese colony.

In relation to the books edited in Portugal, we can observe that there was a prominence of books to mainstream Medicine, as M edicina doméstica, M. R. d'Oliveira (1883); Guia médico-homeophatico familiar ou modo de cada uma se tratar prompta e suavemente das moléstias mais comuns, Ayres B. Pinto (1870); and Diccionario homeopathico portátil de symptomas, Filipe José Rodrigues (1858). They appeared alongside translations such the one made by Hufeland, Arte de prolongar a vida humana ou moderno tratado d'Hygiene (1825) and by Guilherme Buchan, Medicina domestica, ou tratado completo de conservar a saúde, e de curar, e precaver as enfermidades (1788-1803).

The Cabinet also had a substantial amount of dissertations presented in science institutes in Lisbon, such as Dissertação sobre o novo systema do contraestímulo (1816), by Antonio J osé de Sousa Pinto, and dissertations presented by doctoral students of the Medicine College of Rio de Janeiro and Bahia (in large volumes). We can also notice the significant presence of printed works about medicine made by national editors, being a version of books originally published in several languages, such as the renowned Dicionário de medicina popular, by Chernoviz (3rd edition, 1862), and 0 médico do povo, Benoît Mure, translated by J oaquim J osé da Silva Pinto, revised by Dr. A de Castro Lopes and printed by the printing company belonging to A de Castro M elo, in Rio de Janeiro, 1868.

By contrast, we can identify in this collection the presence of classic books, such as the Hippocrates book, and other editions of Portuguese authors from the 17th and 18th centuries (for the most part), besides several books written in Latin language

\footnotetext{
${ }^{51}$ SCHAPOCHNIK, Nelson. Contextos de leitura no Rio de Janeiro do século XIX: salões, gabinetes literários e bibliotecas. In: BRESCIANE, S. (org.). Imagens da cidade séculos XIX e XX. São Paulo, Marco Zero/ANPUH/FAPESP, 1994, p. 147-162.
} 
with different origins such as Institutiones physiologicae et pathologicae, Leopoldo Marc Antonio Caldani, dated 1784, or Institutionum, Caspari Hofmannus, 1645.

Yet, despite noticing a significant presence of classic books, the vast majority of the books kept by the Portuguese Cabinet of Reading in the medical sciences area had been edited in the XIX century, mainly in the second half of the century. Such aspect denotes the effort carried out by the institutional executives with the intention to construct an updated collection, that could be accessed by their members and, that could especially stimulate the membership, as they were paid.

In the Cabinet Board of Leaders we may find the explanation to the existence of this rich and updated collection of books and journals on Medicine, since it was no rare to see physicians working as librarians or even directors of the institution, as we can see in Table 1, previously presented. It is worth mentioning that the collection regarding Medicine included around $8 \%$ of the Cabinet collection, showing the importance of this subject area for the institution. The figures presented in the Table also show the major effort made by their representatives to increase constantly the collection, which, if initially intended to represent the Portuguese culture in the city at the end of the 19th century, had become one of the main libraries in the capital, mainly because of the variety of books and authors available in the shelves of the sumptuous main office, inaugurated in 1887, at Rua Luís de Camões, with Manueline style, in the city center, which was once seat of the Luzo-Brazilian Empire.

Data de recebimento do artigo: 22/01/2016

Data de aprovação do artigo: 10/05/2016

\section{Bibliography}

ABBOT, Andrew. The systems of professions. An essay on the division of expert labor. Chicago and London: The University of Chicago Press, 1998.

AZEVEDO, Fabiano Cataldo. A doação da biblioteca João do Rio ao Real Gabinete Português de Leitura: aspectos de uma histórica pouco conhecida. Perspectivas em ciência da informação, v. 15, n. 3, p. 233-249, set./dez. 2010.

- Contributo para traçar o perfil do público leitor do Real Gabinete Português de Leitura: 1837-1847. Ci. Inf., v. 37, n.2, p 20-31, 2008. 
. 0 acervo bibliográfico do Gabinete Português de leitura como lugar de memória e forma reconhecível: considerações acerca dessas aproximações. Convergência Lusíada, n. 25, p. 43-60, 2011.

BETTIOL, Maria Regina Barcelos. A fundação da Biblioteca Nacional: uma memória compartilhada entre dois mundos. Instituto Histórico e Geográfico do Rio Grande do Sul. Avaliable at:< http://www.ihgrgs.org.br/artigos/contibuicoes/Maria\%20R.\%20B.\%20Bettiol\%2 $\underline{0-}$ \% 20A\%20Funda\%C3\%A7\%C3\%A30\%20da\%20Biblioteca\%20Nacional.pdf>. Accessed in: 12/15/2016.

BLAKE, Augusto Victorino Alves Sacramento. Diccionario bibliographico brasileiro. 1은 volume. Rio de Janeiro: Typographia Nacional, 1883.

BRAGANÇA, Aníbal; ABREU, Márcia (Orgs.). Impresso no Brasil. São Paulo: Ed. Unesp, 2010

DANTES, Maria Amélia Marcarenhas. Fases da implantação da ciência no Brasil. Quipu, México, v. 5, n. 2, p. 265-275, 1988;

DENIPOTI, Cláudio. Normas e gestualidades da leitura em bibliotecas brasileiras do século XIX. Cultura - Revista de História e Teoria das Ideias, vol. 25, 2008.

DOMINGUES, Heloísa Maria Bertol. 0 Jardim Botânico do Rio de Janeiro. In: DANTES, Maria Amélia Mascarenhas. Espaços da Ciência no Brasil. 1800-1930. Rio de Janeiro: Ed. Fiocruz, 2001, p. 27-56.

EL FAR, Alessandra. Ao gosto do povo: as edições baratíssimas de finais do século XIX. In: BRAGANÇA, Aníbal; ABREU, Márcia (Orgs.). Impresso no Brasil: dois séculos de livros brasileiros. São Paulo: Editora Unesp, 2010, p. 89-99. . Páginas de sensação. Literatura popular e pornográfica no Rio de J aneiro (18701924). São Paulo: Companhia das Letras, 2004.

FERREIRA, Luiz Antonio; FONSECA, Maria Rachel Fróes da; EDLER, Flavio Coelho. A Faculdade de Medicina do Rio de Janeiro no Século XIX: a organização institucional e os modelos de ensino. In: DANTES, Maria Amélia Mascarenhas (org.). Espaços da ciência no Brasil. 1800-1930. Rio de Janeiro: Ed. Fiocruz, 2001, p. 59 - 79. 
FERREIRA, Tania Maria Tavares Bessone da Cruz. As bibliotecas públicas cariocas no século XIX. In: INTERCOM, 2011. Available at: http://www.intercom.org.br/papers/nacionais/2001/papers/NP4FERREIRA.pdf. Accessed in: 6/20/2013.

- O que liam os cariocas no século XIX? In: XXVIII Congresso Brasileiro de Ciências da Comunicação, 2005. Available at: http://galaxy.intercom.org.br:8180/dspace/bitstream/1904/17536/1/R20531.pdf. Accessed in: 6/2/2011. . Palácios de destinos cruzados: bibliotecas, homens e livros no Rio de Janeiro (1870-1920). Rio de Janeiro: Arquivo Nacional, 1997.

FIGUEIREDO, Betânia Gonçalves. Os manuais de medicina e a circulação do saber no século XIX no Brasil: mediação entre 0 saber acadêmico e 0 saber popular. Educar, Curitiba, n. 25, 2005, p. 59 - 73.

GALVÃO, Benjamin Franklin Ramiz Galvão (Org.). Catálogo do Gabinete Português de Leitura no Rio de Janeiro. Rio de Janeiro: Typ. do Jornal do Commercio de Rodrigues \& C., 1906.

GONÇALVES, Monique de Siqueira. Livros de ciência médica na Biblioteca Nacional: 0 acervo sobre as doenças nervosas (1860-1880). História Unisinos, 18, 1, p. 146 - 157, 2014. - Livros, teses e periódicos médicos na construção do conhecimento médico sobre as doenças nervosas na Corte Imperial (1850-1880). In: FERREIRA, Tania B. C; RIBEIRO, Gladys S.; GONÇALVES, M onique de S. (Orgs.). 0 Oitocentos entre livros, livreiros, impressos missivas e bibliotecas. São Paulo: Alameda, p. 59 - 87, 2013.

HALLEWELL, Laurence. O livro no Brasil: sua história. São Paulo: Edusp, 2005.

MOREL, Marco. As transformações dos espaços públicos: imprensa, atores políticos e sociabilidades na cidade imperial (1820-1840). São Paulo: Hucitec, 2005.

PIM ENTA, Tânia Salgado. 0 exercício das artes de curar no Rio de Janeiro (1828-1855). Tese (Doutorado em História). São Paulo: UNICAM P, 2003.

RIBEIRO, Gladys Sabina. A liberdade em construção: identidade nacional e conflitos antilusitanos no Primeiro Reinado. Tese (Doutorado em História). Campinas: Unicamp, 1997. 
SCHWARCZ, Lilia M oritz. A longa viagem da biblioteca dos reis: do terremoto de Lisboa à independência do Brasil. São Paulo: Companhia das Letras, 2002.

SCHAPOCHNIK, Nelson. Contextos de leitura no Rio de Janeiro do século XIX: salões, gabinetes literários e bibliotecas. In: BRESCIANE, S. (org.). Imagens da cidade, séculos XIX e XX. São Paulo, Marco Zero/ANPUH/FAPESP, 1994, p. 147 - 162. . Os jardins das delícias: gabinetes literários, bibliotecas e figurações da leitura na corte imperial. Tese (Doutorado em História). São Paulo: Universidade de São Paulo, 1999.

SOARES, Maria Angélica Lau Pereira. Visão da modernidade. A presença britânica no Gabinete de leitura (1837- 1838). Dissertação (M estrado em Estudos linguísticos e literários em inglês). São Paulo: Universidade de São Paulo, 2006.

WEISZ, George. Les transformations de I'Elite medicale em France. Actes de la Recherche en Sciences Sociales, № 74, sept. 1988, p. 33- 46.

VELLOSO, Verônica Pimenta. Farmácia na Corte Imperial (1851-1887): práticas e saberes. Tese (Doutorado em História das Ciências). Rio de Janeiro: Casa de Oswaldo Cruz/Fiocruz, 2007. 